\title{
In-between the Constitution and the European Court of Human Rights: Mobilizations Around Religion and Education in Greece
}

\author{
Margarita Markoviti \\ IE University
}

\begin{abstract}
This paper examines the impact of European Court of Human Rights (ECtHR) decisions on the field of religion and education in Greece around the issues of the content and objectives of religious education, the exemption thereof, and religious symbols in school. The findings indicate that despite the relevance of ECtHR case law with the specific field in Greece, the Court's role in influencing such national debates is minimal. Drawing on empirical research and discourse analysis, the paper argues that this is due to the doctrine of the margin of appreciation, apparently linked to strategic references to and varying interpretations of the Court's judgments; the unwillingness of actors to litigate in a potentially sensitive, lengthy, and costly procedure; and to a shared belief in the perceived primacy of constitutional provisions on religion and education that precludes the formation of structured mobilizations.
\end{abstract}

\section{INTRODUCTION}

In October 2015, former Greek Minister of Education, Nikos Filis, announced his decision to reform the class of religious education (RE), liberating it from its mono-religious focus on Christian Orthodoxy and rendering it more pluralistic. His statements triggered a much wider debate over the nature of church-state relations in the country and sparked an intense, ongoing controversy between the radical left

This work was supported by the FP7 Ideas: European Research Council under Grant 338463.

Address correspondence and reprint requests to: M. Markoviti, Grassrootsmobilise, Hellenic Foundation for European and Foreign Policy (ELIAMEP), Vassilisis Sofias 49, Athens, 10676. E-mail: M.markoviti@eliamep.gr 
government of SYRIZA, its right-wing, nationalist coalition partner, ANEL, and the Orthodox Church ${ }^{1}$.

RE in Greece has formed a wide "cultural (and political) battlefield" (Willert 2014, 12) for the recurrent opposition of conflicting views within the Orthodox Church, amongst theologians, politicians, and the media. Since the formation of the Modern Greek state education has served as a medium to secure and perpetuate the strong relationship between religion and national identity. Amongst few other states in Europe $^{2}$, Greece represents an indicative case of a public education system $^{3}$ in which the class of religion is both compulsory and denominational. The close links between the Greek state and the Orthodox Church are expressed through the absence of separation between the two and through the implications of this interconnection in a number of policy areas and, in particular, in public education. Recently, however, the increasing flows of immigration, the 2015-2016 refugee crisis, together with the emphasis that international human rights institutions have placed on religion and education for the guarantee of religious freedoms and the promotion of social cohesion, have challenged the Greek state's treatment of religious diversity.

In such an effort, the Council of Europe (CoE) seeks to secure, amongst others, freedom of religion and conscience through the ever-expanding jurisprudence of its Strasbourg-based European Court of Human Rights (ECtHR of the Court). The role of the latter has been crucial in resolving disputes that also emerge around religion and education, ensuring the application of Article 9 of the European Convention on Human Rights (ECHR), often taken in conjunction with other Articles ${ }^{4}$. Of all $\mathrm{CoE}$ member states, and according to the Court's 2016 violations report ${ }^{5}$, Greece has received the highest number of convictions by the ECtHR over religious freedoms-related cases. Yet, and in spite of the relevance of ECtHR case law to the salient religion and education issues in Greece, there has been no such mobilization at the Strasbourg Court against the penetration of the prevailing religion in education.

This paper explores the impact of ECtHR religion-related jurisprudence on the religion and education field in Greece. Its originality lies in the adoption of a grassroots perspective to examine the ways in which ECtHR case law infiltrates the domestic field and debates of religion and education. As part of the research project "Grassrootsmobilise" 6 , the study builds on the North-American socio-legal scholarship ${ }^{7}$ that argues that the effects of courts' decisions go well beyond the implementation/ non-implementation dimension, on which the literature has focused thus 
far$^{8}$. It examines the unexplored "radiating" effects (Galanter 1983) of ECtHR case law, by looking at its growing religious freedoms-related jurisprudence, the different messages dispersed from its decisions among national actors, the "rights consciousness raising" (McCann $2004,510)$ and the mobilizations for the promotion of religious pluralism on the ground.

Two underlying questions are addressed: how, if at all, does the Court interact with the embedded culture of education and religion in actors' perceptions of and mobilizations around religious freedoms? And to what extent do ECtHR decisions shape domestic debates, offering the opportunity structures and the incentive for national actors to mobilize in the sphere of religion and education in Greece? Such questions are significant, as they demonstrate the potential of the ECtHR to influence religious pluralism on the ground, exposing the particular factors in Greece that stand as obstacles to this process.

The findings draw on discourse analysis of the key documentation on education and religion, coupled with extensive empirical research conducted in Greece between 2015 and 2017. The fieldwork consisted of participant observation and semi-structured interviews (approximately 50) with a wide selection of national actors involved in the domain: majority religion representatives; minority religious communities and other conscience-based groups; theologians, state and government representatives at the Ministry of Education, Research and Religious Affairs (MoE), education and legal experts, and human rights activists. The questions examined the extent to which national actors are aware of ECtHR religious freedoms jurisprudence and the ways in which they use these decisions in their own efforts to secure rights.

The paper begins with a brief presentation on the background of the religion and education domain in the Greek and ECtHR contexts. It then examines the impact of the Court's case law by focusing on the three debates that the empirical research has exposed as most salient in the country: (i) the content and objectives of RE; (ii) the rules underlying exemption from RE; and (iii) the presence of religious symbols in schools. The findings demonstrate that the effects of the Court's case law on grassroots mobilizations around religion and education are relatively minimal. It concludes that even though the Court's jurisprudence is relevant to religion and education issues in Greece, its potential to influence the field is limited by three factors: first, the varying interpretations of the Court's rulings by grassroots actors, including a particular approach to the margin of appreciation doctrine; second, the unwillingness of national 
actors to litigate through a potentially sensitive, lengthy, and costly procedure; and, third, a shared belief amongst most of the grassroots actors consulted about the ways in which the perceived pervasiveness and primacy of constitutional provisions on religion and education preclude the formation of structured mobilizations "in the shadow" of the ECtHR.

\section{RELIGION AND EDUCATION: GREECE AND THE ECtHR}

Article 3 of the 1975 Constitution of Greece asserts the Eastern Orthodox Church of Christ as the "prevailing" religion. ${ }^{9}$ This declared "prevalence" has attracted a great deal of criticism, which stresses that the advantages enjoyed by the Orthodox Church come to the detriment of other religious communities, leading to human rights violations (Pollis 1992; Kyriazopoulos 2001).

Indeed, in the 1990s, the question of the unequal treatment of religious minorities in Greece was repeatedly brought to the Court in Strasbourg. The case of Kokkinakis v. Greece ${ }^{10}$, involving a Jehovah's Witness, formed the very foundation to the Court's jurisprudence on Article 9 violations and exposed the strict ways in which the constitutional prohibition of proselytism is being implemented in Greece, interfering with the exercise of the right to "freedom to manifest one's religion or belief"11. Kokkinakis crucially opened the way to a number of petitions to the ECtHR by marginalized communities in Greece, involving, indicatively, conscientious objection (Thlimmenos; Papavasilakis), imposition of state requirements contrary to the beliefs of the individual (Efstratiou; Valsamis), refusal of legal personality of Churches (Canea Catholic Church), religious oath for taking office, and the disclosure of one's religion or belief (Alexandridis), the religious oath sworn when testifying before Greek courts (Dimitras and Others), and the authorization to build places of worship (Manoussakis and Others). The Treaty of Lisbon established the ECHR's superiority over Greek national law, while ECtHR judgments are binding for national authorities.

The influence of the Orthodox Church is further diffused in Article 16 (2) of the Constitution, which establishes amongst the objectives of education "the development of [students'] national and religious conscience". RE in Greek public schools is compulsory for all Christian Orthodox students in primary and secondary education ${ }^{12}$ and the content of the class is catechetical, with a disproportional emphasis on Christian Orthodoxy. Other-denominational students may be granted exemption upon 
submitting a declaration indicating that there are reasons related to other doctrines, religions or religious consciousness. The state has moreover to provide RE to any religious community that wishes to organize its own confessional class, provided that a minimum of five students applies for it.

The critique of Article 16 (2) of the Constitution is twofold. It targets, first, the indoctrinating character of the class of religion in Greece, whose objective is not simply to ensure students' knowledge of a specific religion but to cultivate their belonging to this very religion. This objective is affirmed through current Law on Education (1566/1985), which states that the class of "Orthodox Christian Instruction" should help students "to develop into free, responsible, democratic citizens... in whom is instilled a faith in their motherland and in the authentic elements of Christian Orthodox tradition". In accordance, thus, with law 1566/1985, the school curricula and textbooks adopt a principally mono-religious perspective. ${ }^{13}$ This predominance of Christian Orthodoxy is not unique to the class on religion; it infiltrates the entire education system, both through references to the historical links between Orthodoxy and national identity spread throughout other subjects (Zambeta 2003), as well as through rituals that symbolize the control of the Orthodox Church over the school, namely morning prayer and holy blessing, alongside the presence of Orthodox icons in classrooms.

The second part of the critique touches upon the question of who is entitled to teach RE. In Greek primary schools religion is taught by the main class teacher, while in high schools it is taught by theologians who have graduated from either of the two Orthodox Faculties of Theology in Athens and Thessaloniki. This regulation subsequently raises questions regarding theologians' capacity to adopt a pluralistic and objective approach to the teaching of religion.

\section{Religion and education in the ECtHR}

Such questions around religion and education are not unique to Greece. With its ever-expanding jurisprudence around religious freedoms, the Strasbourg Court has addressed some pertinent issues. In Folger $\varnothing$ and Others v. Norway (2007) and in Zengin v. Turkey (2007) the Court examined, respectively, students' right to exemption from a compulsory class of $\mathrm{RE}$, which is not in conformity with their parents' convictions, and the requirement that the instruction provided in schools should meet the 
criteria of objectivity and pluralism. The Court found that information and knowledge in RE in the two countries was not conveyed in an objective, critical and pluralistic manner (Article 2 of Protocol No.1) and that the system of partial exemption in the Norwegian case (wherein the parent could be required to reveal sensitive information about their personal beliefs) was insufficient. In Lautsi v. Italy and in Dahlab v. Switzerland, the issue at stake was the presence of religious symbols in the school ${ }^{14}$ : the Catholic crucifix on classroom walls (Lautsi) and the Muslim headscarf worn by a primary school teacher (Dahlab). In 2001 the Court held that the interference with the teacher's freedom to manifest her religion in the Swiss school was justifiable as a measure to protect the freedoms of others, namely schoolchildren. By contrast, in arguably one of its most controversial judgments in March 2011, the ECtHR reversed its initial decision in Lautsi 1 (2009) and ruled that the presence of the crucifix in the Italian case does not amount to indoctrination and falls within states' margin of appreciation. Finally, in Fernández Martínez v. Spain (2014) the ECtHR ruled that the decision not to renew the contract, as RE teacher, of a Catholic priest who was married and had several children - after his active involvement in a movement opposing Church doctrine had been made public - was legitimate.

This study demonstrates that ECtHR case law is closely relevant to the salient issues in the religion and education field in Greece, namely the content of RE, the exemption process from RE and religious symbols in the school. However, and in spite of Greece's high conviction record in religious freedoms violations in Strasbourg, no such case has reached the Court over the field of religion and education from the country. The following sections discuss the factors that restrict the ECtHR's influence and the formation of grassroots mobilizations.

\section{THE CONTENT AND OBJECTIVES OF RE}

A recurrent question about RE in Greek schools concerns the subject's content and objectives. The heated debates target the denominational character of the subject, which fails to meet the standards set out by ECtHR case law and the $\mathrm{CoE}$ for a neutral, critical, and pluralistic teaching of religion.

Education in Greece falls into the category of national "protected spaces", which European norms find hard to permeate (Wallace qtd in Olsen 2002, 934). The actors consulted indicate that this debate takes place in a national context, under specific conditions that are seen as 
unique to the country. Theologians rarely allude to the Strasbourg Court, which they see as lacking authority to intervene in such sensitive domestic affairs. A theologian based at the Institute of Education Policy of the MoE explained how each decision reached by the Court relates to "... a specific sub-context - either philosophical, ideological, historical or political". It is for this reason that, in his view, a given decision by the Court does not necessarily apply to other countries, meaning that one cannot generalize about the relevance of the Court's jurisprudence.

Yet, one of the key findings of this study is that, even though the ECtHR only features marginally in this debate around the content of $\mathrm{RE}$, its jurisprudence has created a vague but important point of reference to which actors varyingly refer according to their different objectives, levels of awareness and resources.

\section{Two sides of the debate}

Actors in Greece are divided into two camps: the traditionalist side that opposes any changes to the curriculum that may challenge the place of Orthodoxy in education, and the progressive one, which is in favor of a more pluralistic and neutral approach to education. The debate on RE has been taking place since roughly mid-1970s. Its (re)emergence in the 1990s and its consecutive comebacks over the following years cannot be dissociated from the sociodemographic changes, which, as a result of the extended immigration influx ${ }^{15}$, signified that religious diversity has become a reality as much in Greek public schools as in Greek society. Thus, most actors consulted emphasized that, as Greek society became more diverse (also in religious terms) the role and place of religion in public education had to adapt to new standards.

It is no coincidence that theologians, whose very professional interests are linked to the teaching of religion (Willert 2014, 116), are the main actors dictating the terms of this discussion. The theologians who are members or supporters of the Pan-Hellenic Union of Theologians (PETH), a scientific trade union created in 1950, represent the more traditionalist side in this debate, and remain skeptical of any change in the status quo of RE. In 2010 some theologians broke away from PETH and created their own, more progressive but smaller association, named "Kairos". In contrast to the mono-religious outlook of PETH, "Kairos" seeks to "upgrade RE in Greece... (to set the) foundation for the deepening and enrichment of democracy, the encouragement of the elimination of 
prejudices and stereotypes, fostering responsibility and inspiring love for the fellow men" ("Kairos, Declaration of Principles"). The views of these progressive theologians have largely materialized through the creation of the New School project.

\section{THE NEW SCHOOL}

Initiated in 2011 during the Pan-Hellenic Socialist Movement's (PASOK) administration by then MoE, Anna Diamantopoulou, the New School project entails a series of reforms of the current curriculum of various school subjects, including religion. The New School returned to the forefront following SYRIZA's electoral victory in September 2015. As former MoE, Nikos Filis stated the necessity to reform the class of religion on the basis of the new project, actors fervently positioned themselves on either side of the debate. Whether or not this program will eventually replace the long-standing approach to RE is an extremely timely matter. ${ }^{16}$ This apparent change in government discourse and policy introduced a window of opportunity (Koopmans 1999), influencing actors' mobilizations.

According to the creators of the New School, the Strasbourg Court case law does not seem to have served as a reference point in their endeavor. Nonetheless, a careful reading of the founding documents stating the project's objectives suggests an important degree of influence from the European recommendations on religion and education, especially as these stem from the CoE's "Religious Diversity and Intercultural Education" and the Toledo Guiding Principles on Teaching about Religions and Beliefs in Public Schools of the Organization for Security and Cooperation in Europe (2007). In the first place, the New School conceptualizes RE as a subject that is "open and pluralistic" (Yangazoglou 2011). Targeting, moreover, the denominational character of $\mathrm{RE}$ and taking into consideration the changes in the country's population, the New School seeks to integrate the reality of religious diversity into the school through the study of not only the Christian traditions of Europe, but also of Judaism, Islam, Hinduism, Buddhism, Taoism, and Confucianism, with a special focus on Judaism and Islam. Christianity, however, does not lose its central position in this new project, whose objective is, after all, to "build on and to broaden the already existing religious experience and understanding of students" (New School: Teacher's Guide 2014, 88; Yangazoglou 2013).

The above reasoning echoes the arguments presented by the Norwegian government in Folger $\varnothing$ v. Norway concerning the alleged neutrality and 
pluralistic approach to religion in the class on Christianity, religion, and philosophy ("KRL"). Similar to the Greek New School, the Norwegian state argued that KRL was designed to promote understanding, tolerance, and respect among pupils of different backgrounds while informing them of the history and values of Norway, where approximately $85 \%$ of citizens were Lutheran Christian. The applicants, who were members of the Norwegian Humanist Association, submitted that KRL was neither objective nor critical nor pluralistic and that a core purpose of the class was to strengthen the pupils' own Christian foundation, which violated their right to have their children taught in conformity with their own convictions. The Grand Chamber ruled that KRL violated Article 2 of Protocol No. 1 of the ECHR. It held, specifically, that Christianity accounted for about half of the material in the KRL curriculum, with other beliefs only marginally represented, and maintained that the system for a partial exemption from KRL was insufficient. In spite of the evident parallels between the ECtHR judgment in Folger $\phi$ and the New School approach to RE, the discussion below demonstrates that the Strasbourg Court's role is overshadowed by widespread perceptions of religion and education, which use the constitutional provisions and national legislation as obstacles to mobilization.

The New School has thus preserved emphasis on Christian Orthodoxy; yet it constitutes the main point of contention between the two camps of theologians. Whereas the more progressive circles of theologians consider the CoE and the Court as helpful in the designing of the project, the traditionalist camp adopts a much more critical, if not altogether negative, stance. In their view, the New School is a threat to the religious tradition and national identity of young people in Greece. Their main weapon in opposing any changes is recourse to the Constitution and the respective legislation, which, as they claim, leave little room for doubt over the place of religion in education. The following excerpt from an interview with one of the representatives of the traditionalist circle of theologians reflects not only the ways in which the Constitution is given precedence over other types of authority but, moreover, how the ECtHR is, itself, in line with these very constitutional provisions:

As the Constitution asserts, one of the objectives of education is "the development of the religious consciousness of students", which means that we should teach [students] about their own faith. [...] To do otherwise, means to proselytize, it means a lack of respect for the Constitution and for the ECtHR, since you are not respecting someone else's religion! What this new program [the New School] does, is to 
brainwash 8-year-old children. They are asking us to "punish" our children by forcing them to learn about nine different religions. This is definitely a lack of respect for one's freedom of education. ${ }^{17}$

Along similar lines, PETH's legal counselor argued that any changes in the class of RE would challenge the constitutional provision that guarantees the teaching of the prevailing religion: "Could we abolish the Constitution? Of course not!"18. Such statements are indicative of the commonly shared view that stresses the distant role of the Convention and of the ECtHR vis-à-vis the "protected space" of education.

ECtHR jurisprudence interacts with a socio-legal culture in Greece that is strongly based on the pre-eminence of a constitutional doctrine (Psychogiopoulou 2010), which, with few exceptions, is shared by most of my interlocutors in either the traditionalist or more progressive circles. A constitutional law expert and former Greek Minister of the Interior with extensive experience in Church-state relations described this as a culture of "constitutional lust", where, due to the lack of political consensus, recourse to the Constitution is seen as the only viable solution to such controversial questions. Particularly concerning the role of the Orthodox Church in education, the Constitution is used as a fixed source, "almost like a holy text that settles everything". He argues, however, that the Constitution is the pretext and not the actual problem:

The Constitution is not the obstacle; rather, they cannot find a political solution to their issue (of religion and education), so they resort to the Constitution. [...] But there exists no one single interpretation (of the Constitution); there are many. As with the many interpretations of a religious text, laws, and especially the Constitution may - fortunately - have many interpretations. ${ }^{19}$

The above is one of the few voices of those actors involved in the field who challenge the common conceptualization of the Constitution as static and as inhibiting alternative interpretations. A human rights lawyer and activist with much experience in Strasbourg is similarly critical of this idea that the Constitution "prohibits change", which he describes as "ludicrous". Though acknowledging that it would have been better had certain parts not been included in the Constitution - those pertaining to the prevalence of the Orthodox Church and the prohibition of proselytism - he believes that the Constitution is used as an excuse "only (by) those who wish to prevent changes and developments" 20 . In addition to the other factors discussed here that render mobilizations by the Strasbourg Court around religion and education unlikely, one of the key findings of the empirical research demonstrates the extent to which such a view of the Constitution 
as opposing and superior to the ECtHR is used by grassroots actors to either resist or be sceptical of litigation in the religion and education domain.

\section{The orthodox church, religious minorities, and the atheist union}

Actors other than theologians participate in the debate on the content of $\mathrm{RE}$, often in an ardent manner. In the first place, this study brings to light the polyphony within the Orthodox Church (Willert 2014) on the specific issue. Archbishop Ieronymos has repeatedly taken a stance on the topic, criticizing the SYRIZA government for allowing an ongoing discussion on the teaching of RE. In one such intervention, he interprets any discussions to change RE as impositions from "Europeans" who, by taking "advantage of (Greece's) dire economic situation, [...] seek to distort Greek society in any possible way, starting with education" 21.

The distinct views of the Metropolitan Bishops on RE have ranged from neutral to extreme. The Bishop of Piraeus has criticized any attempt to transform RE into a "postmodern" class of "religious studies", arguing that the classes of Islam in Western Thrace and Catholicism in Syros ${ }^{22}$ testify to the fact that, where necessary, RE is pluralistic. Though rejecting claims that in its current form RE is indoctrinating, a more moderate Metropolitan Bishop acknowledges that there are some weaknesses in the way in which religion is being taught. He believes that, as its main objective, this class "should offer students the kind of knowledge and information that contributes to the development of an integrated personality". ${ }^{23}$

The different religious minority communities also express their views on the matter, but the question of RE does not figure amongst their priorities. Though they do recognize the preferential treatment of Christian Orthodoxy in schools, the possibility of exemption from the class, though not always smooth and simple, ${ }^{24}$ offers a convenient and relatively easy solution. As mentioned above, every student in Greek schools has a right to ask for an exemption from RE via a declaration, indicating that there are reasons related to other doctrines, religion or religious consciousness (Koukounaras Liagkis 2015, 3). Such an option appears to be available exclusively to non-Orthodox students.

Members of the Jewish and the different Muslim and Buddhist communities interviewed share this view and claim that, very often, non-Orthodox students do not even ask for an exemption. Some concerns on the content 
of RE were, however, expressed by certain religious minority groups. A member of the Church of Scientology complained about the use of the term "sect" in the RE textbooks to describe their community, whose negative connotation alluded, in her view, to "heresy". Similarly, legal counselors of Jehovah's Witnesses in Athens referred to an issue of biased references to their community in the textbook for the second year of high school, which had been resolved with the aid of the Greek Ombudsman. Indeed, though the Jehovah's Witnesses have lodged the majority of applications against Greece in Strasbourg over religionrelated issues, none of these cases concerned RE. As the interviews revealed, this is due to the fact that members of the community are satisfied with the option of exemption, which they moreover actively use as a means to declare their belonging in the particular religion.

It seems, therefore, that the class of RE is an essentially Orthodox dispute. The one type of mobilization that is determined to intervene is the recently emerging atheist movement, represented primarily by the Atheist Union of Greece. Established in 2010 and with some 1500 members, the Union's claims do not concern exclusively education, but a number of policies, laws and practices regulating religion in the Greek public sphere: the separation of church and state, the laws prohibiting blasphemy, the civil naming of children - as opposed to religious baptism -, cremation, political oath before courts, and others.

Members of the Atheist Union explained how education forms one of the main targets of their campaign because of its intertwining with the Orthodox Church. The ECtHR case law does not seem to influence their arguments with respect, specifically, to the content of RE, since their utmost objective is the abolition of the class altogether. Given the unlikelihood of such a development, they aim instead at the reduction of school hours dedicated to RE (from 2 hours per week to 1) and at the transformation of RE into a subject of religious studies. As we will see further on, the Union currently focuses on the option of exemption from RE for all (and not only for non-Orthodox students), also turning to the ECtHR jurisprudence to shape their claims.

\section{OPPORTUNITY STRUCTURES AND EXEMPTION FROM RE}

The Atheist Union mobilization relates to the second salient issue that concerns the opt-out option from the class of RE available to non-Orthodox students. Recently, this aspect was brought back to the fore only days after 
SYRIZA's second victory. On September 25, 2015, Sia Anagnostopoulou, former Alternate Minister of Education, announced her intention to simplify the exemption process, adding that parents should be allowed to simply ask that their child does not take the class of religion, with no reference - either positive or negative - to their religion. ${ }^{25}$ Following reactions by Archbishop Ieronymos, and though Anagnostopoulou revoked her initial position, such statements were enough to spark another debate. As with the content of RE, the political opportunity structure was provided for actors to mobilize towards the pursuit of their claims in relation, this time, to the exemption.

Almost all interviewees agree that only a small minority of students actually asks to be exempted from RE, usually Jehovah's Witnesses or Muslims. Two crucial issues emerge over exemption, both of them relating to ECtHR case law (in Folger $\phi$ and Zengin): the legitimacy of the procedure in effect and the necessity for exemption altogether. With the exception, however, of secularist/atheist mobilizations, the Strasbourg Court does not shape the terms of the domestic debate on this particular issue either.

\section{The controversy around government circulars}

The rules underpinning the exemption process are set by government circulars, which serve to clarify legislative regulations, aiding the civil servants in the realization of their work. The current circular (issued on January 23, 2015, hence, before the SYRIZA administration) states that the exemption procedure from the compulsory class of $\mathrm{RE}$ is in line both with Article 16 of the Constitution and with "the decisions of international and Greek courts". It further specifies that "[...] non-Orthodox students, meaning heterodox or those of other faiths, are given the possibility of exemption, invoking reasons of religious conscience $[\ldots]$ ". The controversy emerges specifically through the conditions for exemption:

As on some occasions [...], an exploitation of the right to exemption related to freedom of religious conscience has been observed, school directors are asked to inspect the validity of the reasons presented, stressing the gravity of the Formal Declaration to all those interested [...]. Exemption from the class of RE is granted only following submission of the Formal Declaration by the student (if he/she is an adult) or by both his/her parents (if he/she is a minor), which should state that the student is not Christian Orthodox and has, thus, the right to claim reasons of religious conscience, without the obligatory reference to his/ her religion, unless he/she so wishes. 
The vast majority of theologians, on both the traditionalist and progressive sides, stressed the need to render requirements for exemption stricter. One RE school counselor in Athens also noted the negative impact of religious freedoms in this case since, "rather than exemption being a measure that guarantees the religious needs and freedoms of individuals, it is used by students so that they have one less subject to study". ${ }^{26}$

The requirements listed in this circular still in force, which arguably renders exemption stricter than the one that preceded it (that had required solely the submission of the declaration of exemption without providing a reason for this request), have given rise to debates about the disclosure of personal information. In spite of its related rulings, the ECtHR does not play an important role in actors' claims. Folger $\phi v$. Norway was only invoked (though not by name) by an actor who engages with issues to do with RE at the MoE. He explained that "according to the Rome Protocol, parents can intervene in their children's education if it is not in conformity with their beliefs", pointing out, however, that "the Norwegian example shows us that one has to justify [the reasons for asking for exemption]". ${ }^{27}$ Supporting the view that the SYRIZA government is in favor of the implementation of the New School, he further believes that the latter will render the question of exemption irrelevant.

Regardless of the changes in the content of RE, it is rather unlikely that the New School project would satisfy the criteria that the ECtHR has set out in Folger $\phi$. An education expert who was in charge of drafting the first (eventually dropped) version of RE for the New School, expressed her disappointment over the fact that RE in the New School still remains a predominantly Christian Orthodox subject. Indeed, if the New School were to be examined in the context of Folger $\phi$, its disproportionate attention to the prevailing religion, the teaching of the class by theologians trained in Orthodox Faculties and the abolition of the exemption alternative would raise serious questions of compatibility with ECtHR jurisprudence.

\section{Exemption and the Hellenic data protection authority (HDPA)}

Grassroots actors in Greece are primarily interested in the role of national legal authorities in questions of exemption, while the Court in Strasbourg remains on the sidelines. A human rights lawyer and founding member of the Humanist Union of Greece did emphasize his intention to take one such case over an exemption to the Strasbourg. He explained the 
reasons why he believes, parents are skeptical of the exposure that litigation may have on their children:

We have been trying to find one parent who would be willing to take this to the ECtHR for years! We are desperately trying to find one such parent, but even activists are skeptical because they are afraid of the implications of this on their children at school. Which is understandable. ${ }^{28}$

The key group of actors that seeks to take advantage of the apparent windows of opportunity offered by the change in political discourse is the Atheist Union. Its members are concerned about the power attributed to school authorities who eventually decide whether students are entitled to exemption or not. Their most structured mobilization came in the form of a complaint to the HDPA. This is not the first time that the HDPA, an independent body whose decisions are binding, has been asked to intervene in such matters. In 2002, following complaints by a number of students' parents, the HDPA asked the then MoE to modify the circular in force at the time. According to the HDPA's ruling, the declaration of students' non-Orthodox religion as a precondition to exemption constituted a breach of their personal information. A legal counselor of the HDPA in charge of the 2002 proceedings explained how the ECtHR was then taken into consideration and was included in the final text of the Authority's decision. He added, moreover, that in spite of their direct appeal to the MoE, the HDPA's ruling was to no avail.

Thirteen years later, in February 2015, the Atheist Union, who saw SYRIZA's victory as a possible ally in their campaign ${ }^{29}$, requested the HDPA's intervention for the modification of the January 2015 circular on the exemption. According to a member of the Atheist Union, this circular - which divides students along Orthodox/non-Orthodox lines - does not consider the rights of students who do not belong to either of the two categories, such as atheists or agnostics. Interestingly, the Union relied on a particular ECtHR case (Alexandridis v, Greece) that did not concern education, but rather the case of Mr Alexandridis who had to disclose his non-Orthodox religious beliefs when swearing before a national court to take office as an advocate. It became clear through our discussion that the Union members were, in fact, unaware of other ECtHR cases relevant to exemption from RE. Lack of knowledge and of legal expertise, as they explained, was primarily due to their limited resources, which signified that they could not maintain permanent legal counselors, but rather relied on lawyer friends who voluntarily offered their services.

The Atheist Union asked that the circular be altered in a way that is respectful of the rights of parents who, for reasons of conscience, wish 
that their children be granted an exemption. As the Union's report to the HDPA further notes, the exemption regulation violates the rights of citizens for the protection of their sensitive personal data, such as religion. This recourse to the HDPA is connected with the case of a mother whose child was denied exemption on the grounds that he had been baptized Greek Orthodox. After consulting with the Greek Ombudsman, the mother decided to take this case to national courts. In such a legal struggle, the possibility of reaching Strasbourg seemed - according to one representative - like a desirable, yet distant, target for the Atheist Union. Their main concern with such a prospect was due to the delay caused by the precondition to exhaust domestic remedies before Strasbourg and with the question of financial resources.

The legal counselor of the conservative Union of Theologians (PETH) soon reacted to the Atheist Union's appeal, through a report to the HDPA that referred to the recent ruling of a national court, which, as he claimed, resolved the matter decisively:

The matter under investigation has already been definitively resolved through decision 115/2012 of the Chania Administrative Court of Appeal [...], which asserts that the class of RE is compulsory for all Orthodox students. The court's decision further adds that, even when one of those (Orthodox students) asks for an exemption, invoking reasons of conscience, he is committing the crime of submitting a false declaration before a public authority $[\ldots] .{ }^{30}$

Eventually, in August 2015 the HDPA's decision stated: "[...] since no religious (or non-religious) justification has to be provided in the exemption form, the current procedure does not violate law $2472 / 1997$ on the protection of the personal information of students". ${ }^{31}$ According to a legal counselor of the HDPA, there are clear discrepancies between the Authority's 2015 decision and its intervention back in 2002. He believes the latter to be much closer to ECtHR jurisprudence, since in its 2015 ruling the Authority did not consider the negative disclosure of the sensitive information of students, meaning their right not to declare which religion they do not belong to. In his understanding, it is not just the declaration of one's religion that leads to discrimination; as dictated by the current circular, the exemption procedure may also lead to discrimination, "particularly in the microcosm of the Greek school, [where] such differences are conspicuous 32 ". It was, finally, the HDPA counselor's impression that this recent problematic decision, though reached as a means to maintain a balance in the church-state controversy, represented a step backward in the question of exemption and of RE overall. 


\section{RELIGIOUS SYMBOLS IN SCHOOL}

The omnipresence of Christian Orthodoxy in the Greek school is further guaranteed through the presence of religious symbols, most often icons in the classroom depicting Jesus Christ or Virgin Mary. It is no coincidence that perhaps with the exception of Kokkinakis, no other ECtHR case was evoked - though not always by name - in the interviews as frequently as Lautsi v. Italy. The indirect effects of Lautsi in the Greek context, and the different interpretations and uses of this particular case, are an indicative example of how a single judicial action may radiate different messages to different audiences (Galanter 1983, 126) offering important insight into a more general understanding of and stance in relation to the ECtHR case law amongst my interviewees.

In spite of their disagreement over the content and objectives of RE, Lautsi seems to unite traditionalist with progressive theologians and members of the Orthodox Church. The traditionalist view adapts Lautsi to the Greek context, where the respective question would involve the presence of religious (Orthodox) icons in school classrooms. The legal counselor of PETH drew a comparison between Kokkinakis and Lautsi over the question of proselytism in the following way:

When the case (Lautsi 1) reached the Grand Chamber, [...] the legal advisors of the Italian MoE approached me. And I told them that if you take the Kokkinakis case together with Lautsi (1), then one contradicts the other because Kokkinakis says that there has to be some kind of pressure exerted (as part of the act of proselytism). By contrast, the crucifix on the wall does not exert any kind of pressure; and the Court, itself, realized that. Given that (the crucifix) is simply hanging on the wall, this is not proselytism. As far as the ECtHR is concerned, the question of proselytism has thus been resolved. ${ }^{33}$

According to this view, the second decision of Lautsi helped ensure a necessary degree of consistency in the Court's jurisprudence. More importantly, this interpretation of the Lautsi judgment seeks to respond to any critical voices that request the removal of religious symbols from Greek public schools.

Even the more progressive actors underline the minimal relevance of the specific ECtHR case to the Greek context. Rather, such voices echo the Italian government's intervention in Lautsi and emphasize the need to respect religious symbols as part of Greece's history and tradition. In the words of a theologian, member of "Kairos" and active supporter of the New School: 
But why would the symbol of a religion bother us? I think we have to simply respect them and accept them, particularly in the light of a prevailing religion, which has shaped the country's culture and has influenced its history. I think that it is hypocritical, in the name of modernization, not to respect these symbols. ${ }^{34}$

The effects of Lautsi on Greek society crucially reflect the extent to which an ECtHR judgment may directly influence actors' decision to mobilize (or not to mobilize) in another country. Indeed, because of the similarities between the Italian and Greek contexts in terms of the presence of religious symbols of the majority religion in schools, the Court's final decision in Lautsi 2 had a profound impact upon the motivations of those activists in Greece who hoped to see in the Italian case an opportunity to claim their rights. In the words of a Greek human rights lawyer and member of the Humanist Union:

The change in the Lautsi verdict destroyed everything. We had even mobilized against religious symbols in Greek courts [...]. Lautsi was a big drawback, at a European level, which we would not be able to overcome soon ${ }^{35}$.

It appears thus that the Court's judgment in Lautsi has acted as a hindrance for those actors in Greece who sought to challenge the status $q u o$, as it directly diminished their expectations - and their determination to litigate - over the removal of Orthodox icons from classrooms walls.

\section{The margin of appreciation and varying interpretations of ECtHR case law}

In the aftermath of Lautsi, a tendency to emphasize the margin of appreciation granted to national authorities was shared by most actors consulted. The doctrine of the margin of appreciation has been developed in an attempt to strike a balance between national views of human rights and the uniform application of Convention values (Christoffersen 2011). The rationale behind this principle was set out in Handyside $v$ the United Kingdom, where the Court decided that, because of their direct and continuous contact with the forces of their countries, national authorities are "in a better position than the international judge to give an opinion on the exact content of these requirements as well as on the "necessity" of a "restriction" or "penalty" intended to meet them". In spite of a certain degree of autonomy granted to states, the margin of appreciation goes hand in hand with European oversight, while in some 
areas the Court has decided to give very little if any, margin to states. This applies to matters in which the Court considers there to be a "pan-Europe consensus"36; due to the variations in the place of religion in European societies, Article 9 religious freedom cases do not, however, fall in this consensus category (Evans 2009, 215).

In its 2011 ruling in Lautsi 1, the Grand Chamber granted Italian authorities a margin of appreciation over the presence of the crucifix, alongside recognition of the fact that the Italian education system provides a religiously pluralistic and tolerant space that does not pursue an aim of indoctrination. The majority of actors consulted in Greece largely ignore or are unaware of the above reasoning of the Court and tend to focus, instead, on the margin of appreciation, which is interpreted as a means that justifies the choices of the state over matters of religious manifestation in school (and not only). Such a view is reflected through the arguments of a traditionalist theologian, member of PETH, who, based on Lautsi, significantly minimizes the overall impact of the Court over matters of religious and national identity, while granting precedence to the provisions of the Constitution:

What do these international human rights courts say? That each country is free to do as it wishes. That each country should teach RE according to its Constitution. [...]. Yes, this case was about the religious icons [sic] in Italy [...]. But the second decision by the Court stated that this practice (or religious icons) is tradition, a part of history that has influenced everything. ${ }^{37}$

A Metropolitan Bishop stressed in a similar manner the value of such customs in the Greek tradition. Implicitly referring to the first ECtHR judgment in Lautsi in 2009, in favor of the removal of the crucifix, he criticized the Court's role in challenging social cohesion:

I wonder what the main criterion of judgment is in the Court's decisions. Should not this criterion be societal cohesion? [It appears] that the Court shifts the focus from the majority to the minority (of the population), which should not, however, determine the course of the majority. [...] The minority cannot impose its own interests [over the majority]... otherwise; we would run the risk of polarization, which is a challenge to societal cohesion. ${ }^{38}$

The above is the kind of critique that, though directed towards the interests of a given majority, requires a certain knowledge of the Court's functioning.

Insight gathered from the interviews suggests that grassroots actors in Greece either make strategic interpretations of the Court's rulings or are 
unaware of its actual decision and rationale. The former was the case with a founding member of the Atheist Union who, when the name of Lautsi came up, quickly reacted: "Yes, of course, Lautsi! But do they apply this decision by the Court here [in Greece]? No, they do not!" 39. In her impression of the Strasbourg Court as an ally in the Atheist Union's struggle to control the excessive power of religion, this actor's reaction was to take for granted that the Lautsi ruling asked for the removal of religious symbols from schools. After informing her of the Court's final ruling in Lautsi, she was skeptical of the implications of this in the Greek context, where, as she claimed, the prevalence of Christian Orthodoxy was secured by the Constitution. Her initial reaction nonetheless suggests that levels of awareness and knowledge of the Court's case law determine, to a great extent, actors' perceptions of the Court's relevance for the Greek RE context.

Such a finding further applies to those actors who demonstrate a better understanding of the Court's case law and function. A progressive theologian spoke to me about the mobilizations in Greece after Lautsi 1, and estimated that the Court had then sought to find a balance that would satisfy both sides. If Lautsi were to be hypothetically placed in a Greek context he was certain that the Court would not have reached the same verdict. Otherwise, "the entire class of RE would have to be abolished!" 40 . This view reflects an understanding of the nuances in the Court's final decision in Lautsi as well as of the particularities of the Greek field of RE, which in light of its indoctrinating character and the presence of religious icons would render a similar ruling by the Court unlikely.

\section{CONCLUSION}

This study on the mobilizations around religion and education in Greece has demonstrated that ECtHR judgments meet and interact with a legal culture that is strongly based on the pre-eminence of a constitutional doctrine. With the exception of few of the actors consulted who are involved in the field, the majority of grassroots actors consider that the Constitution and the laws regulating education leave little space for manoeuvring over the place of religion. According to this interpretation, the protection of the prevailing position of the Orthodox Church by the Constitution renders ECtHR case law secondary and any mobilizations of national actors by the Strasbourg Court pointless. Subsequently, either traditionalist actors, who oppose change, or those belonging to more progressive circles and 
who do wish to mobilize, as is the case of the Atheist Union, tend to perceive of national laws as an obstacle, which, regardless of ECtHR jurisprudence, guarantees the advantageous position of the Orthodox Church in the education sphere.

Though the Strasbourg Court's jurisprudence is both relevant and may offer opportunities for mobilization (around the content of RE, exemption rules or religious symbols) these are further undermined by a particular understanding of the doctrine of the margin of appreciation. Relying on the latter, the Court's decisions related to religion are seen as malleable and are adapted each time to the views, objectives, and knowledge of the society and culture in question. As Galanter explains, what the Court has done may be inaccurately perceived; indeed, the Court itself may have inaccurately depicted what it has done $(1983,125)$. Nowhere has this been more pronounced than in the case of Lautsi v. Italy in Greece. Indeed, the potential of this single case in influencing national debates and mobilizations cannot be overstated. On the one hand, Lautsi has shaped the arguments of traditionalist actors, who see the Grand Chamber's ruling as the justification of their claims on the importance of the prevailing religion and on letting national authorities have the final word. More progressive actors, on the other hand, usually from the atheist/humanist milieus, see Lautsi as a drawback that directly hinders mobilization around similar issues from and within Greece.

These factors, together with skepticism over the implications that litigation in such sensitive matters may entail - particularly for children of younger age - as well as a lack of resources, help explain why, in spite of Greece's high conviction record by the ECtHR in religion-related cases, no application has yet reached Strasbourg concerning the field of religion and education from Greece.

The research has demonstrated, however, that one of the indirect effects of the Court's jurisprudence has been the creation of an opportunity space within which national actors may gain awareness of their rights, form opinions on different matters and even mobilize. This is reflected primarily through the atheist and humanist movements, which have sought to use the Court for the framing of their claims in legal terms and the setting of their agenda to mobilize before national authorities and the media.

Finally, another dimension of this mobilization process is the political and social changes that affect the place of religion in the education system. Both the SYRIZA government's inclination to challenge the status quo and the influx of populations of different origins (and religions) into the country yielded the opportunity for some flexibility. It remains to 
be seen whether the New School for RE will eventually materialize and the extent to which it will comply with ECtHR case law. Such steps are significant as they offer actors the opportunity to voice their different views and they may gradually inspire further interaction between ECtHR judgments and national laws and values around religion and education.

\section{Acknowledgments}

\section{The author would like to thank the entire Grassrootsmobilise team for their comments, as well as the anonymous reviewers for their helpful feedback.}

\section{NOTES}

1. See "Education minister's row with Church intensifies", Kathimerini, September 23, 2016 : http://www.ekathimerini.com/212277/article/ekathimerini/news/education-ministers-row-with-churchintensifies [accessed January 3, 2018]

2. See Hunter-Henin (2011).

3. Public education refers to schools whose organization, financing, and management are primarily the responsibilities of a public body.

4. For instance, Articles 10 (freedom of expression), 11 (freedom of assembly and association), 13 (right to an effective remedy), 14 (prohibition of discrimination), and Article 2 of Protocol No. 1 (respect for parents' philosophical convictions).

5. http://www.echr.coe.int/Documents/Stats_violation_1959_2016_ENG.pdf [accessed December 30, 2017].

6. The research was conducted under the auspices of the European Research Council-funded Grassrootsmobilise program (grant agreement no 338463).

7. See McCann (2006) and Fokas (2015b)

8. See Bjorge (2015) and Anagnostou (2013).

9. Greece is among several other European Union countries that do not collect data on ethnic, religious or linguistic aspects of their populations. According to the World Factbook of the Central intelligence Agency, 98\% of the Greek population is Christian Orthodox: https://www.cia.gov/library/ publications/the-world-factbook/geos/gr.html [accessed October 30, 2017].

10. In May 1993, the ECtHR ruled that the applicant, Mr Kokkinakis', imprisonment and conviction for proselytism, after engaging in discussion the wife of a cantor of the local Orthodox Church, constituted a violation of Article 9 of the ECHR.

11. During the dictatorship of General Metaxas (1936-1940), proselytism was made a criminal offence (Obligatory Law 1363/1938). In the current Constitution, Article 13 (2) also mandates the prohibition of proselytism.

12. Public education in Greece consists of 6 years of primary school, 3 years of middle school, and 3 years of high school.

13. Mono-religious education focuses on just one religion to which pupils are introduced (see Hermans 2003).

14. See also Sahin v Turkey (no. 44774/98) and Osmanoğlu and Kocabaş v Switzerland (no. 29086/12).

15. See, http://www.iom.int/countries/greece/facts-and-figures [accessed January 3, 2018] and https:// webgate.ec.europa.eu/fpfis/mwikis/eurydice/index.php/Greece:Population:_Demographic_Situation, Languages_and_Religions [accessed January 3, 2018].

16. See "Religious Education in Greece", The Economist, October 11, 2015: http://www.economist. com/blogs/erasmus/2015/10/religious-education-greece [accessed October 11, 2015].

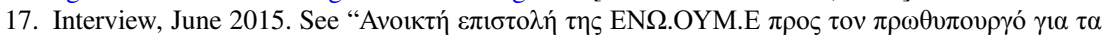




religious symbols], January 27, 2010: http://thriskeftika.blogspot.com.es/2010/01/blog-post_7349. html [Accessed December 18, 2017].

18. Interview, May 2016.

19. Interview, August 2016.

20. Interview, January 2017.

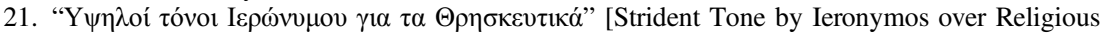
Education], October 7, 2015, Kathimerini: http://www.kathimerini.gr/833791/article/epikairothta/ ellada/yyhloi-tonoi-ierwnymoy--gia-ta-8rhskeytika [accessed January 4, 2018].

22. The Muslim minority of Western Thrace is composed of people of Turkish origins, Pomak,s and Tziganes. Dictated by the Treaty of Lausanne (1923), the minorities of this region have a distinct educational system, with emphasis on Islamic religion. Additionally, around 50,000 Greek Catholics reside mainly in Athens, while around 8,000 live in the Cycladic island of Syros and 3,000 in Tinos, where denominational school establishments are found.

23. Interview, January 2016.

24. See Fokas 2015a.

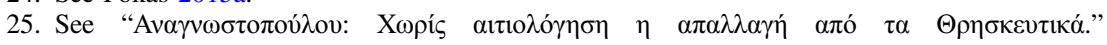
[Anagnostopoulou: No justification for exemption from Religious Education.], September 25, 2015, To Vima: http://www.tovima.gr/society/article/?aid=740572 [accessed January 3, 2018].

26. Interview, May 2015.

27. Interview, October 2015.

28. Interview, January 2017.

29. Members of the Atheist Union emphasized the symbolic significance of certain acts of PM Alexis Tsipras in raising public awareness about the Atheist Union, such as his civil oath to the PM's office, and his civil union with his partner.

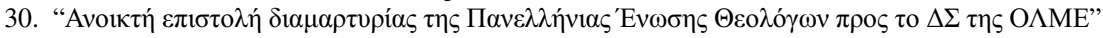
[Open letter of Complaint by PETH to the Council of OLME], Athens, September 25, 2015: http:// www.petheol.gr/nea/anoikteepistolediamartyriastespanelleniasenosestheologonprostodstesolme [accessed May 30, 2017]

31. See http://www.dpa.gr/portal/page?_pageid=33,131633\&_dad=portal\&_schema=PORTAL [accessed January 3, 2018].

32. Interview, February 2016.

33. Interview, May 2016.

34. Interview, December 2016.

35. Interview, January 2017.

36. This is not always the case, however, since Handyside v. United Kingdom (in 1976), in which the Court developed the doctrine of the margin of appreciation, came before the Court had introduced the concept of consensus, with the case Rasmussen v. Denmark in 1984 (Fokas 2015b).

37. Interview, June 2015.

38. Interview, January 2016.

39. Interview, September 2015.

40. Interview, September 2015.

\section{REFERENCES}

Anagnostou, Dia, eds. 2013. The European Court of Human Rights: Implementing Strasbourg's Judgments on Domestic Policy. Great Britain: Edinburgh University Press.

Bjorge, Eirik. 2015. Domestic Application of the ECHR. Courts as Faithful Trustees. New York: Oxford University Press.

Christoffersen, Jonas. 2011. "Individual and Constitutional Justice: Can the Power Balance of Adjudication be Reversed". In The European Court of Human Rights Between Law and Politics, eds. Jonas Christoffersen and Mikael Rask Madsen. Oxford: Oxford Scholarship Online, 181-203.

Evans, Malcolm D. 2009. "The Freedom of Religion or Belief and the Freedom of Expression". Religion and Human Rights 4: 197-235. 
Fokas, Effie. 2015a. "Banal, Benign or Pernicious? Religion and National Identity From the Perspective of Religious Minorities in Greece". New Diversities 17(1): 47-62.

Fokas, Effie. 2015b. "Directions in Religious Pluralism in Europe: Mobilizations in the Shadow of European Court of Human Rights Religious Freedom Jurisprudence". Oxford Journal of Law and Religion 4(1): 54-74.

Galanter, Marc. 1983. "The Radiating Effects of Courts". In Empirical Theories About Courts, eds. Keith O. Boyum and Lynn Mather. New York: Longman, 117-142.

Hermans, Chris A. M. 2003. Participatory Learning. Religious Education in a Globalizing Society. Leiden: Brill.

Hunter-Henin, Myriam. 2011. Law, Religious Freedoms and Education in Europe. Farnham: Ashgate.

Koopmans, Ruud. 1999. "Political. Opportunity. Structure. Some Splitting to Balance the Lumping”. Sociological Forum 14(1): 93-105.

Koukounaras Liagkis, Marios. 2015. "Religious Education in Greece: A New Curriculum, an Old Issue". British Journal of Religious Education 37(2): 153-169.

Kyriazopoulos, Kyriakos N. 2001. "The "Prevailing Religion" in Greece: Its Meaning and Implications". Journal of Church and State 43(3): 511-538.

McCann, Michael. 2004. "Law and Social Movements". In Blackwell Companion to Law and Society, ed. Austin Sarat. Oxford: Blackwell, 506-522.

McCann, Michael. 2006. "Law and Social Movements: Contemporary Perspectives". Annual Review of Law and Social Science 2: 17-38.

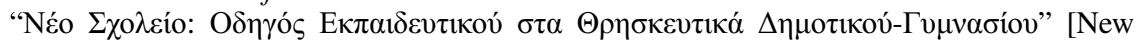
School: Teacher's Guide for Religious Education in Primary School and Gymnasio]. 2014. Ministry of Education and Religions, Institute of Educational Policy. Revised

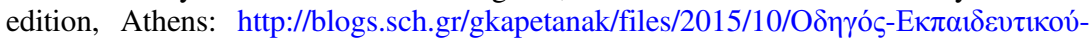
$\sigma \tau \alpha-\Theta \rho \eta \sigma \kappa \varepsilon v \tau \iota \kappa \alpha ́-\Delta \eta \mu о \tau \iota \kappa о v ́-Г v \mu \nu \alpha \sigma i ́ o v-10.12 .2014$.pdf (accessed January 3, 2018).

Olsen, Johan P. 2002. "The Many Faces of Europeanization". Journal of Common Market Studies 40(5): 921-952.

Pollis, Adamantia. 1992. "Greek National Identity: Religious Minorities, Rights and European Norms". Journal of Modern Greek Studies 10(2): 171-191.

Psychogiopoulou, Evangelia. 2010. "The European Court of Human Rights in Greece”. In The European Court of Human Rights and the Rights of Marginalised Individuals and Minorities in National Context, eds. Dia Anagnostou and Evangelia Psychogiopoulou. Leiden: Martinus Nijhoff Publishers, 115-135.

"Toledo Guiding Principles on Teaching about Religions and Beliefs in Public Schools". 2007: http://www.osce.org/odihr/29154 (accessed January 3, 2018).

Willert, Trine Stauning. 2014. New Voices in Greek Orthodox Thought. Untying the Bond Between Nation and Religion. Abingdon: Ashgate.

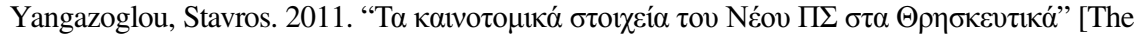
New School and the Innovative Features of the Program of Study in Religious Education]: http://e-theologia.blogspot.gr/2011/10/blog-post_7251.html (accessed January 3, 2018).

Yangazoglou, S., Athanasios Nevrokoplis, and Georgios Striligkas, eds. 2013. Ta

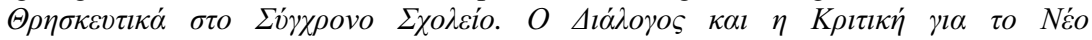

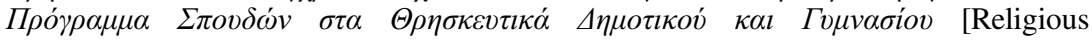
Education in the Modern School. Dialogue and Critique on the New Program of Study of Religion in Dimotiko and Gymnasio]. Athens: Armos.

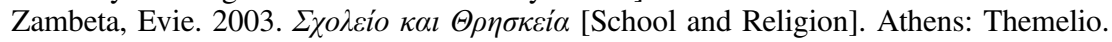

